\title{
Ciliary Motility Defect
}

National Cancer Institute

\section{Source}

National Cancer Institute. Ciliary Motility Defect. NCI Thesaurus. Code C84638.

Defective movements of the cilia. It includes abnormal movements of the cilia in the nose and paranasal sinuses, the respiratory tract and spermatozoa. 